\title{
A Survey Study of the Effects of Preschool Teachers' Beliefs and Self-Efficacy towards Mathematics Education and Their Demographic Features on 48 - 60-Month-0ld Preschool Children's Mathematic Skills
}

\author{
Perihan Tuğba Şeker ${ }^{1}$, Fatma Alisinanoğlu² \\ ${ }^{1}$ Department of Early Childhood Education Department, Education Faculty, Usak University, Usak, Turkey \\ ${ }^{2}$ Department of Child Development, Gelisim University, Istanbul, Turkey \\ Email: tugba.seker@usak.edu.tr, alisinanf@gmail.com
}

Received 28 February 2015; accepted 16 March 2015; published 19 March 2015

Copyright (C) 2015 by authors and Scientific Research Publishing Inc.

This work is licensed under the Creative Commons Attribution International License (CC BY). http://creativecommons.org/licenses/by/4.0/

(c) (i) Open Access

\section{Abstract}

This research has been performed for examination of affect on belief and self efficacy of preschool teachers about mathematics education on the math skills of 48 - 60 months old children. Three separate data collection tools were used in the study. The study population is $48-60$ months children who attend to an independent National Education Ministry nursery school of Ankara Province, Cankaya Town in 2012-2013 education year. The study aimed to reach all of the population. In the research, "The General Information Form", "The Belief Survey", "TEMA-3 Early Mathematics Ability Test" and "The Self-Efficacy of Scale Pre-School Teachers for Mathematics Education" were used in order to get information about children and their families. "Beliefs Survey", was developed by Platas (2008) and adapted by Şeker (2013), "TEMA 3 Test of Early Mathematics Ability", developed by Ginsburg and Barody and adapted by Şeker in 2013 and "Self-efficacy Scale of Preschool Teachers towards Mathematics Education" which developed by Șeker (2013), were used in the study. It was determined that the level of the self-efficacy of the preschool teachers was high in both dimensions in the study. The total point of the teachers from the Beliefs Survey has a positive and high-level relationship with the appropriate age, occupational development and teacher sub-dimensions in mathematics education. However, the total point is in a negative and high-level relationship (-0.918) with teacher points in terms of focus of knowledge. After the analysis of math skills of 48 - 60 months children, it was determined that respectively the level of teachers' beliefs were significantly predicted by age ranges of children, mothers' education level, previously attend pre-school education institution status, gender, father's education level, teachers' level of 
education, teachers working period in the institution and mothers' working status for the math skills of children.

\title{
Keywords
}

\author{
Pre-School Education, Early Mathematics Education, Pre-School Teacher, Self-Efficacy, Belief, \\ Demographic Features
}

\section{Introduction}

Preschool children have informal mathematics knowledge and it must be accepted that conscious adults, peers, materials, interactions and conscious opportunities, can structure this knowledge. It is true that children have natural curiosity and learning eagerness during preschool. Based on this truth, parents and educators can teach children mathematics concepts and skills with enjoyable and exciting methods (Charlesworth \& Lind, 2013: p. 6).

In the studies conducted on the quality of education in pre-school period, one of the most emphasized issues is the teacher-student communication. In order to give a quality education, the teacher must have an adaptive, creative, investigative, and flexible characteristic (Kandır, İnal, \& Özbey, 2010). For the teachers, being ready for the mathematics education is crucial and occasionally difficult situation. Generally, to teach mathematics, one must have a strong mathematic and pedagogic background. NCTM (National Council of Teachers of Mathematics), in its Professional Standards for Teaching Mathematics (1991), emphasizes that "the teacher must endeavor to make the concepts and principles of mathematics deeply understood and to provide that the subjects of mathematics or its relations with other disciplines are formed”. In pre-school period, which is outstanding in raising the individuals and accepted as a critical period in one's life, laying the foundations of the academic skills, especially mathematics skills, is essential. Therefore, as it is well known, the person who will support the developing of these skills in those years is the pre-school teacher who is taken as a role model after the child's parents. It is thought that the ideas, beliefs and self-efficacy beliefs of the pre-school teachers on mathematics education affect the implementations in the education process.

According to Copley (2004), early childhood teachers are generally described as lacking confidence in teaching math. Few studies have examined teacher confidence in relation to teaching tasks such as planning learning activities or assessing children's math understanding and Sarama and DiBase (2004) said young children's performance in mathematics depends on their teachers' mathematical proficiency (Chen, Cray, Adams, \& Leow, 2013). Generally, survey studies are limited and based on self-report data and observation. So this study has been performed for examination of affect on belief and self efficacy of preschool teachers about mathematics education on the math skills of 48 - 60 months old children.

\section{Method}

The study aims at researching the effects of preschool teachers' beliefs and efficacy for mathematics education on mathematics skills of 48 - 60-month-old children. The study population is 48 - 60 months children who are attend to an independent National Education Ministry nursery school of Ankara Province, Cankaya Town in 2012-2013 education year. The study aimed to reach all of the population. In the research, "The General Information Form”, "Beliefs Survey”, "TEMA-3 Early Mathematics Ability Test” and "The Self-Efficacy of Scale Pre-School Teachers for Mathematics Education" were used in order to get information about children and their families. The study, when examined in terms of its aim, it is an example of survey research design. Survey research is a research approach which aims at representing a situation which existed or still exists as it was or is (Karasar, 2008: p. 77).

According to Creswell (2009), survey research is the quantitative or numerical representation of the attitudes, opinions and tendencies of a group. According to Büyüköztürk and others (2010: p. 231), survey researches are the researches which determine participants' thoughts related to the subject or the situation or their interests, talents, attitudes or similar features and which are usually done on larger samples compared to other researches. "Beliefs Survey", "TEMA 3 Test of Early Mathematics Ability" and "Self-efficacy Scale of Preschool Teachers towards Mathematics Education” were used in the study. 


\subsection{Belief Scale of Preschool Teachers towards Mathematics Education}

“Beliefs Survey of Preschool Teachers towards Mathematics Education”, developed by Platas (2008) and adapted by Şeker (2013). Beliefs Survey of Preschool Teachers towards Mathematics Education was developed by Platas (2008) to be used in her study of PhD thesis. It was adapted by Şeker (2013) within her doctorate thesis. In her study, the pre-application of the "Beliefs Survey" adaptation form had been carried out with 255 pre-school teachers. Primarily, commentary factor analysis then confirmative factor analysis was accomplished with the guidance of the responses received from the teachers. In order to carry out such analysis, firstly, the KMO value was calculated as 0.830 . And belief scales’ lower dimensions are observed, it can be stated credible.The scale consists of 40 items and is a 6-point likert scale.

\subsection{Test of Early Mathematics Ability (TEMA-3)}

“TEMA 3 Test of Early Mathematics Ability”, developed by Ginsburg and Barody and adapted by Şeker in 2013. TEMA-3 was developed by Ginsburg and Baroody in 1983 to assess the mathematics skills of children between 3 - 8. It was revised and in 1990 and published as TEMA-2. The validity and reliability tests of TEMA-2 in Turkey were done by Güven (1997) was proved to be a valid and reliable scale. TEMA-2 test was revised later and was developed as TEMA-3 in 1993 (Ginsburg \& Baroody, 2003). The adaptation of TEMA-3 to 60 - 72 month-old children in Turkey was done by Erdoğan and Baran (2006) and it was found to be a valid and reliable scale. It was adapted to 48 - 60-month-old children by Şeker (2013) and was proved to be a reliable and valid test.

\subsection{Self-Efficacy Scale of Pre-School Teachers towards Mathematics Education}

“Self-Efficacy Scale of Pre-School Teachers towards Mathematics Education” was developed to define the selfefficacies of the teachers working in pre-school institutions towards the teaching of mathematics to pre-school period children. The scale was graded in 5 Likert-type items and the gradations are "Totally Agree-AgreeNeutral_Disagree-Totally Disagree”. There are 36 items in the Self-Efficacy Scale and all of the items are positive.The reliability coefficient of the first dimension of the scale is 0.95 ; the reliability coefficient of the second dimension is 0.951 ; the reliability coefficient of the overall scale is 0.967 . In naming of the factors of the 2-factor self-efficacy scale, by taking the opinions of the field experts, the first factor that have 20 items was named as self-efficacy towards preparing mathematics activities in pre-school period and the second factor including the other items was named as self-efficacy towards applying mathematics activities in preschool period.

\subsection{Data Collection}

The study consists of 48 - 60-month-old children and their preschool teachers. There are 10 independent kindergartens of the state in Çankaya, Ankara. However, the study was done in eight independent kindergarten, because it was not possible to do it in two schools.

In the study, the data was collected from 20 teachers and 371 children who are 48 - 60-month-old preschool children to determine the relationship between the preschool teachers' level of belief and self-efficacy and children's mathematics skills.

The descriptive statistics of the data from the study (participant number, minimum, maximum, average, standard deviation) were firstly calculated. Then, the data was analyzed in the direction of the problems of the study. In the analysis of the data, Mann Whitney U test and Kruskall Wallis test were used to determine if the self-efficacies of the teachers changed according to their demographical features. As the number of the teachers was low, the scores of the teachers didn't have a normal distribution, and consequently non-parametric statistics were used.

In unrelated measures, $t$ test and one way analysis of variance statistics (ANOVA) were used to determine if children's mathematics skills changed or not according to their demographic features. Before the statistics were used, it was determined that the data had a normal distribution and the variances were homogeneous.

Hierarchical regression analysis was applied to examine the effect of preschool teachers' beliefs and efficacies towards mathematics education on mathematics skills of 48 - 60-month-old children. Hierarchical multiple regression analysis is a multivariate statistical analysis and before applying the regression analysis, firstly, the hypothesis of the analysis were examined. Accordingly, it was checked if there was a missing data in the unit set. 
It was determined that the number of observation in the study was enough for multiple regression analysis. The scores related to the variables were turned into $\mathrm{z}$ statistics, and Mahalonobis distance amount was also calculated. Univariate and multivariate extreme value was not found in the data set. Histogram graphics and coefficients of skewness and kurtosis were examined to determine the normality distribution of the variables and the variables didn't have a deviation more than normality. The relations among the variables were examined firstly for the multicollinearity problem; it was found out that the coefficient of correlation was between 0.664 and -0.801 . Moreover, it was determined that VIF value which was calculated for multicollinearity was less than 10, and tolerance values were more than 0.10 . The homogeneity of the variables was calculated with Box's M test and it was found that homoscedasticity hypothesis was proved. Finally, it was determined that the coefficient of Durbin Watson which was calculated to determine autocorrelation was 1.740. As this value is between 1.5 and 2.5 , it is seen that there is no autocorrelation among the variables.

In the hierarchical regression analysis, the demographical variables of the preschool children were categorical; categorical variables of gender, age gap, work status of mother, education level of mother, education level of mother, number of siblings and previous experiences of preschool were assigned as “dummy”. In regression analysis which keeps categorical data, a new artificial variable is created by leaving out one of the levels of categorical variables. It is produced as one level less than the level number $\left(\mathrm{g}^{-1}\right)$ and is called "dummy" variable. It can be concluded that if one of the new variables has a meaningful effect on the dependent variable, that means the related independent variable has meaningful effect on the dependent variable (Büyüköztürk, 2008).

The findings from the analysis of the data were shown in tables and the results were interpreted.

\section{Results}

The findings of the study are given below in the direction of sub-goals.

\section{1) What is the level of the self-efficacy of the participant preschool teachers towards mathematics edu-} cation?

The teachers were applied a five graded scale which consisted of 36 items and two dimensions to determine the self-efficacies of preschool teachers towards mathematics education. Maximum, minimum, average and standard deviation values which were calculated related to the scores of the teachers from the scale are shown in Table 1.

When Table 1 is examined, there are 20 items in the dimension of preparation of mathematics activities, first dimension of the self-efficacy scale of mathematics education and the minimum score to get from this dimension 20 and the maximum is 100. The average of the scores of the self-efficacy of the preschool teachers towards the preparation of mathematics activities is 86 . As the average score is closer to the maximum score to get from the dimension, it was determined that the level of the self-efficacy of the preschool teachers towards the preparation of mathematics activities was high.

16 items scale were applied to the teachers to determine the self-efficacy of the teachers towards the implementation of the mathematics activities, which is the second dimension of the scale in Table 1. The minimum score to get from the dimension is 16 , and the maximum is 80 . It was found that the minimum score of the self-efficacy of the teachers towards the implementation of the mathematics activities is 48 , and the maximum is 76. It was determined that the self-efficacy of the teachers towards the implementation of the mathematics score is 65.15. It was found that the level of the self-efficacy of the teachers towards the implementation of the mathematics activities was also high.

When the data in Table 1 was examined, it was found that the teacher who got the minimum score of 20 participant teachers scored 116, and the teacher who got the maximum scored 176 from the self-efficacy scale towards mathematics education (whole scale). The minimum score to get from the self-efficacy scale of the preschool teachers towards mathematics education is 36 , and the maximum is 180 . The average score calculated in the direction of the answers of the teachers towards the mathematics education is 151.15. As the average of the self-efficacy of the teachers towards mathematics education is closer to the maximum score to get from the scale, it was found that the level of the self-efficacy of the preschool teachers towards mathematics education was high.

It was determined that the level of the self-efficacy of the preschool teachers was high in both dimensions in the study.

Aksu (2008) made some analysis according to the differentiation of the primary school, science and preschool teacher candidates according to their beliefs of self-efficacy towards mathematics education, gender, majors and 
Table 1. Descriptive Statistics related to self-efficacies of the teachers towards mathematics education.

\begin{tabular}{cccccccc}
\hline Scale & Number of Items & N & Min & Max & $\overline{\boldsymbol{X}}$ & SD \\
\hline Preparation dimension & 20 & 20 & 60 & 100 & 86.00 & 13.58 \\
Implementation dimension & 16 & 20 & 48 & 76 & 65.15 & 7.44 \\
Self-efficacy scale & 36 & 20 & 116 & 176 & 151.15 & 20.16 \\
\hline
\end{tabular}

departments at high school. After the research of Aksu, it was determined that teacher candidates had high tendency in terms of the self-efficacy towards mathematics education and sub-dimensions of handling. It was found there were no meaningful differences among teacher candidates in terms of their departments. The number of the studies which were done to measure the perception of the self-efficacy of the preschool teachers towards mathematics education is really limited. Studies are generally about teacher candidates. For this reason, the present study has the findings to contribute to the field.

When the data in Table 2 was examined, it was seen that the scores of the participant preschool teachers from the occupational self-efficacy scale had a positive and high-level relationship with the sub-dimensions of the scale (r: 0.981; 0.940). Similarly, it was determined that there was also a high level relationship between the subdimensions (efficacy of preparing activities-efficacy of implementing the activities) of the self-efficacy of the teachers towards mathematics education ( $\mathrm{r}$ : 0.855). In the table, the relationship between the scores of the preschool teachers from the Beliefs Survey towards mathematics education and the sub-dimensions of the scale is seen. The total point of the teachers from the Beliefs Survey has a positive and high-level relationship with the appropriate age, occupational development and teacher sub-dimensions in mathematics education. However, the total point is in a negative and high-level relationship $(-0.918)$ with teacher points in terms of focus of knowledge.

This situation shows that teacher-centered education is adopted as the points from the dimension of focus of knowledge get high. In this respect, it is usual that there is a negative relationship between teachers' focus of knowledge points and other sub-dimensions. When the relationship between the scores of the children from TEMA-3 mathematics skills test in Table 2 and the teachers' belief and self-efficacy scores, it was determined that the relationship between the scores of the children from TEMA-3 and the scores of the self-efficacy of the teachers towards mathematics education is positive (0.664).

It was found in the study that as the level of beliefs of the preschool teachers towards mathematics education increased, the children's mathematics talents score increased as well. When the analysis was examined, it was seen that in the focus of knowledge sub-dimension, as the teachers' belief levels towards children centered approach in mathematics education increased, the children's mathematics skill scores went up. Moreover, when the teachers' belief levels towards teacher-centered approach in mathematics education increased, the children's mathematics skill scores decreased. It is believed that the teachers' belief levels affect both the expectations of the teachers from the children and the opportunities they provide to the children.

48 - 60-month-old children's mathematics skills improve as their teachers' self-efficacy levels increase. Additionally, the belief levels of the teachers towards mathematics education are directly related to the mathematics skills of the children. The teachers' beliefs towards mathematics education and their perception of the self-efficacy towards mathematics education directly affect the teachers' in-class practices. As a result, the children's mathematics skills improve.

2) How much are 48 - 60-month-old children's mathematics skills predicted by their preschool teachers' beliefs towards mathematics education, teachers' self-efficacy and some demographic features?

It was aimed to determine how much 48 - 60-month-old preschool children's mathematics skills are predicted by their teachers' beliefs and self-efficacies towards mathematics education, their demographic features (seniority, period of work in the school, graduation departments) and children's own demographic features (age gap, gender, work status of mother, education level of mother, education level of father, number of siblings, experience of kindergarten). As the self-efficacy scale of teachers towards mathematics education and the Beliefs Survey of teachers towards mathematics education have a high-level relationship, multicollinearity problem will occur in multiple regression analysis. For this reason, regression analysis was done with the inclusion of every dimension of "Beliefs Survey" into the analysis.

In Table 3 are the results of the regression analysis which was done to determine how much 48 - 60 monthold preschool children's mathematics skills are predicted by their teachers' beliefs and self-efficacies towards 
Table 2. The relationship between the 48 - 60 year-old preschool children's mathematics skills and their teachers' level of belief towards mathematics education and level of self-efficacy.

\begin{tabular}{|c|c|c|c|c|c|c|c|c|c|}
\hline & $\begin{array}{c}\text { Efficacy } \\
\text { preparation }\end{array}$ & $\begin{array}{c}\text { Efficacy } \\
\text { implement }\end{array}$ & $\begin{array}{l}\text { Efficacy } \\
\text { total }\end{array}$ & $\begin{array}{l}\text { Appropriate } \\
\text { age }\end{array}$ & $\begin{array}{l}\text { Knowledge } \\
\text { focus }\end{array}$ & Development & Teacher & Belief & TEMA-3 \\
\hline Efficacy preparation & 1 & & & & & & & & \\
\hline Efficacy implement & $0.855\left(^{* *}\right)$ & 1 & & & & & & & \\
\hline Efficacy total & $0.981\left(^{* *}\right)$ & $0.940\left(^{* *}\right)$ & 1 & & & & & & \\
\hline Appropriate age & $0.774\left(^{* *}\right)$ & $0.672\left(^{* *}\right)$ & $0.763\left(^{* *}\right)$ & 1 & & & & & \\
\hline Knowledge focus & $-0.805\left(^{* *}\right)$ & $-0.708\left(^{* *}\right)$ & $-0.797\left(^{* *}\right)$ & $-0.984\left(^{* *}\right)$ & 1 & & & & \\
\hline Development & $0.755\left(^{* *}\right)$ & $0.673\left(^{* *}\right)$ & $0.751\left(^{* *}\right)$ & $0.954\left(^{* *}\right)$ & $-0.978\left(^{* *}\right)$ & 1 & & & \\
\hline Teacher & $0.736\left(^{* *}\right)$ & $0.633\left(^{* *}\right)$ & $0.723\left(^{* *}\right)$ & $0.934\left(^{* *}\right)$ & $-0.906\left(^{* *}\right)$ & $0.856\left(^{* *}\right)$ & 1 & & \\
\hline Belief to plam & $0.687\left(^{* *}\right)$ & $0.591\left(^{* *}\right)$ & $0.675\left(^{* *}\right)$ & $0.964\left(^{* *}\right)$ & $-0.918\left(^{* *}\right)$ & $0.908\left(^{* *}\right)$ & $0.953\left(^{* *}\right)$ & 1 & \\
\hline TEMA-3 & $0.678\left(^{* *}\right)$ & $0.576\left(^{* *}\right)$ & $0.664\left(^{* *}\right)$ & $0.905\left(^{* *}\right)$ & $-0.907\left(^{* *}\right)$ & $0.890\left(^{* *}\right)$ & $0.838\left(^{* *}\right)$ & $0.862\left(^{* *}\right)$ & 1 \\
\hline
\end{tabular}

Table 3. Multiple Regression Analysis (appropriate age sub-dimension) to explain the mathematics skills of preschool children (48 - 60 month-old).

\begin{tabular}{|c|c|c|c|c|c|}
\hline Değişken & $\mathbf{B}$ & SH & $\boldsymbol{\beta}$ & $\mathbf{t}$ & $p$ \\
\hline Appropriate age & 0.909 & 0.044 & 0.810 & 20.816 & 0.000 \\
\hline agedumy_2 & -4.091 & 0.585 & -0.155 & -6.995 & 0.000 \\
\hline Mother education dumy & -10.231 & 1.659 & -0.304 & -6.166 & 0.000 \\
\hline Kindergarten dumy & 2.413 & 0.540 & 0.092 & 4.469 & 0.000 \\
\hline Gender dumy & 1.744 & 0.491 & 0.071 & 3.554 & 0.000 \\
\hline Father education dumy & 5.133 & 1.573 & -0.142 & -3.264 & 0.001 \\
\hline Age dumy_1 & 1.764 & 0.621 & 0.062 & 2.840 & 0.005 \\
\hline Education_dumy 1 & 1.796 & 0.652 & 0.070 & 2.756 & 0.006 \\
\hline Education_dumy 3 & -2.754 & 1.007 & -0.074 & -2.735 & 0.007 \\
\hline Job & 1.557 & 0.653 & 0.053 & 2.385 & 0.018 \\
\hline Mother job dumy & -2.458 & 1.237 & -0.061 & -1.987 & 0.048 \\
\hline Self efficacy & -0.037 & 0.023 & -0.056 & -1.637 & 0.102 \\
\hline Priority & -0.444 & 0.420 & -0.029 & -1.055 & 0.292 \\
\hline Education_dumy 2 & 1.211 & 1.333 & 0.024 & 0.909 & 0.364 \\
\hline Brothe rdumy & 0.056 & 0.508 & 0.002 & 0.111 & 0.912 \\
\hline
\end{tabular}

Note: Model (R: 0.944; R²: 0.891, F (15.370): 192.988, $p=0.000)$.

appropriate age in mathematics education, their demographic features (seniority, period of work in the school, graduation departments) and children's own demographic features (age gap, gender, work status of mother, education level of mother, education level of father, number of siblings, experience of kindergarten).

In the table, the variables of self-efficacy level of the teachers towards mathematics education, educational background (dummy 1) and number of siblings don't explain the change in the mathematics skills of children meaningfully. The variable that contributes most to the explanation is the level of belief of the teachers that the preschool children are at the appropriate age for mathematics education. It was found that the variable which contributes least to the explanation is the work status of mother.

In Table 4 are the results of the regression analysis which was done to determine how much 48 - 60 monthold preschool children's mathematics skills are predicted by their teachers' beliefs and self-efficacies towards focus of knowledge dimension in mathematics education, their demographic features (seniority, period of work in the school, graduation departments) and children's own demographic features (age gap, gender, work status of mother, education level of mother, education level of father, number of siblings, experience of kindergarten). 
When the data in Table 4 was examined, it was seen that the belief dimension of the teachers towards focus of knowledge in mathematics education and 10 variables out of 14 in the regression analysis predicted the mathematics skills of the children meaningfully.

Belief levels of the teachers towards focus of knowledge in mathematics education, the second dummy variable created for the age gap of the children, educational background of mothers, experience of kindergarten, selfefficacy levels of the teachers towards mathematics education, first dummy variable created for year gap, gender, educational background of fathers, the third dummy variable created for the educational background of teachers and work status of mothers explain $90 \%$ of the change in the level of mathematics skills of children.

The work period of the teachers of the children, first and second dummy variables created for their educational background, their seniority and number of siblings don't predict the mathematics skills of the children meaningfully.

The coefficient of the regression of the relationship between the belief level of the teachers towards focus of knowledge in mathematics education and the level of mathematics skills of the children is negative and highlevel $(-0.929)$. It was found when the teachers were in the focus of knowledge in mathematics education, the mathematics skills level of the children decreased. When the belief levels of the teachers towards children-centered approach in mathematics education increased, the mathematics skills level of the children also improved. It was found that the children who were in the class of the teachers who adopted children-centered approach had higher-level mathematics skills.

The self-efficacy level of the teachers towards mathematics education predict the change in the mathematics skills of the children meaningfully although it is different from the regression equalities between the belief level of the teachers that the preschool children must be at the appropriate age for mathematics education. When the coefficient $(-0.135)$ of regression of the teachers' self-efficacy level was examined, it was determined that as the teachers' level of self-efficacy towards mathematics education increased, the children's mathematics skills level decreased.

In Table 5 are the results of the regression analysis which was done to determine how much 48 - 60-monthold preschool children's mathematics skills are predicted by their teachers' beliefs and self-efficacies towards mathematical development as a goal of teachers in preschool education, their demographic features (seniority, period of work in the school, graduation departments) and children's own demographic features (age gap, gender, work status of mother, education level of mother, education level of father, number of siblings, experience of kindergarten).

Table 4. Multiple Regression Analysis (focus of knowledge sub-dimension) to explain the mathematics skills of preschool children (48 - 60-month-old).

\begin{tabular}{|c|c|c|c|c|c|}
\hline Değişken & $\mathbf{B}$ & SH & $\boldsymbol{\beta}$ & $\mathbf{t}$ & $p$ \\
\hline Knowledge focus & -0.872 & 0.039 & -0.929 & -22.375 & 0.000 \\
\hline Agedumy_2 & -4.032 & 0.559 & -0.153 & -7.207 & 0.000 \\
\hline Mother education dumy & -9.666 & 1.595 & -0.287 & -6.060 & 0.000 \\
\hline Kindergarten dumy & 2.428 & 0.518 & 0.093 & 4.687 & 0.000 \\
\hline Self efficacy & -0.090 & 0.023 & -0.135 & -3.953 & 0.000 \\
\hline Age dumy_1 & 2.069 & 0.598 & 0.073 & 3.461 & 0.001 \\
\hline Gender dumy & 1.240 & 0.464 & 0.050 & 2.674 & 0.008 \\
\hline Father education dumy & 3.996 & 1.507 & -0.111 & -2.652 & 0.008 \\
\hline Education_dumy 3 & -2.842 & 0.965 & -0.077 & -2.945 & 0.003 \\
\hline Mother job dumy & -2.508 & 1.186 & -0.062 & -2.115 & 0.035 \\
\hline Job & -1.031 & 0.619 & -0.035 & -1.667 & 0.096 \\
\hline Education_dumy 2 & -1.140 & 0.689 & -0.044 & -1.656 & 0.099 \\
\hline Education_dumy 1 & 2.070 & 1.285 & 0.041 & 1.611 & 0.108 \\
\hline Priority & -0.351 & 0.400 & -0.023 & -0.879 & 0.380 \\
\hline Brother dumy & -0.309 & 0.486 & -0.011 & -0.635 & 0.526 \\
\hline
\end{tabular}

Note: Model (R: 0.947; R²: 0.897, F (15.370): 238.655, $p=0.000)$. 
When the data in Table 5 was examined, it was seen that the belief dimension of the teachers towards mathematical development as a goal of preschool education and 10 variables out of 14 in regression analysis predicted the mathematical skills of the children meaningfully.

Work period of the teachers of the children, first and second variables created for their educational background, their self-efficacy level towards mathematics education and the gender of the children and number of their siblings don't predict the mathematics skills of the children meaningfully.

In Table 6 are the results of the regression analysis which was done to determine how much 48 - 60-monthold preschool children's mathematics skills are predicted by their teachers' beliefs and self-efficacies towards

Table 5. Multiple Regression Analysis (mathematical development sub-dimension as a goal of preschool education) to explain the mathematics skills of preschool children (48 - 60-month-old).

\begin{tabular}{|c|c|c|c|c|c|}
\hline Değişken & B & SH & $\boldsymbol{\beta}$ & $\mathbf{t}$ & $p$ \\
\hline Math development & 1.760 & 0.095 & 0.863 & 18.433 & 0.000 \\
\hline Age dumy_2 & -4.207 & 0.627 & -0.159 & -6.711 & 0.000 \\
\hline Mother education dumy & -11.038 & 1.764 & -0.328 & -6.257 & 0.000 \\
\hline Kindergarten dumy & 3.231 & 0.573 & 0.123 & 5.638 & 0.000 \\
\hline Mother job dumy & -2.989 & 0.698 & -0.102 & -4.282 & 0.000 \\
\hline Age dumy_1 & 5.873 & 1.679 & 0.163 & 3.497 & 0.001 \\
\hline Priority & 3.731 & 1.450 & 0.074 & 2.573 & 0.011 \\
\hline Education_dumy 3 & -1.225 & 0.473 & -0.080 & -2.591 & 0.010 \\
\hline Father education dumy & -1.909 & 0.816 & -0.074 & -2.341 & 0.020 \\
\hline Job & -2.966 & 1.316 & 0.074 & -2.254 & 0.025 \\
\hline Education_dumy 1 & -2.095 & 1.081 & 0.057 & 1.938 & 0.053 \\
\hline Gender dumy & 1.240 & 0.659 & 0.044 & 1.882 & 0.061 \\
\hline Self efficacy & 0.957 & 0.514 & 0.039 & 1.863 & 0.063 \\
\hline Education_dumy 2 & -0.012 & 0.024 & 0.018 & 0.505 & 0.614 \\
\hline Brother dumy & 0.006 & 0.541 & 0.000 & 0.011 & 0.991 \\
\hline
\end{tabular}

Note: Model (R: 0.939; $\mathrm{R}^{2}$ : 0.876, F (15.370): 167.291, $\left.p=0.000\right)$.

Table 6. Multiple Regression Analysis (teacher sub-division in mathematics education) to explain the mathematics skills of preschool children (48 - 60-month-old).

\begin{tabular}{|c|c|c|c|c|c|}
\hline Değișken & $\mathbf{B}$ & SH & $\boldsymbol{\beta}$ & $\mathbf{t}$ & $p$ \\
\hline Teacher & 1.859 & 0.171 & 0.489 & 10.880 & 0.000 \\
\hline Age dumy_2 & -6.420 & 0.731 & -0.243 & -8.784 & 0.000 \\
\hline Mother education dumy & -10.996 & 2.147 & -0.327 & -5.122 & 0.000 \\
\hline Father education dumy & 4.282 & 0.821 & 0.167 & 5.219 & 0.000 \\
\hline Kindergarten dumy & 2.425 & 0.700 & 0.092 & 3.464 & 0.001 \\
\hline Education_dumy 1 & 1.832 & 0.509 & 0.120 & 3.603 & 0.000 \\
\hline Education_dumy 3 & -3.894 & 1.299 & -0.105 & -2.997 & 0.003 \\
\hline Job & -3.662 & 1.604 & -0.091 & -2.283 & 0.023 \\
\hline Age dumy_1 & 3.929 & 2.027 & 0.109 & 1.938 & 0.053 \\
\hline Mother job dumy & 1.528 & 0.855 & 0.052 & 1.788 & 0.075 \\
\hline Education_dumy 2 & 0.046 & 0.029 & 0.068 & 1.584 & 0.114 \\
\hline Self efficacy & 0.801 & 0.634 & 0.033 & 1.264 & 0.207 \\
\hline Gender dumy & 0.453 & 0.796 & 0.016 & 0.570 & 0.569 \\
\hline Priority & -0.280 & 1.719 & -0.006 & -0.163 & 0.871 \\
\hline Brother dumy & -0.065 & 0.655 & -0.002 & -0.099 & 0.921 \\
\hline
\end{tabular}

Note: Model (R: 0.904; R²: 0.818, F (15.370): 106.435, $p=0.000)$. 
teacher in mathematics education of the children, their demographic features (seniority, period of work in the school, graduation departments) and children's own demographic features (age gap, gender, work status of mother, education level of mother, education level of father, number of siblings, experience of kindergarten).

When the data in Table 6 was examined, it was seen that the belief dimension of the teachers towards teacher in mathematics education and 8 variables out of 14 in regression analysis predicted the mathematical skills of the children meaningfully.

Respectively, the belief levels of the teachers towards teacher in mathematics education, second dummy variable created for children's age gaps, educational background of mothers, educational background of fathers, experience of kindergarten, first and third variables created for the teachers' educational background and work period of the teachers at the schools explain $82 \%$ of the change in the level of mathematics skills of the children.

\section{Discussion}

In results, when the coefficient $(-0.135)$ of regression of the teachers' self-efficacy level was examined, it was determined that as the teachers' level of self-efficacy towards mathematics education increased, the children's mathematics skills level decreased. The decrease of the mathematics skills level of the children of the teachers with high-level of self-efficacy can be explained with teachers' being less capable of practices, or teachers' lack of knowledge about what kind of education should be given to which age group in mathematics education. Studies, which include the comparison of mathematics practices and teachers' perception of self-efficacy towards mathematics, must be done to make the correct explanation. For example, in their studies, Aslan, Bilaloğlu and Aktaş Arnas (2006) made individual interviews with 22 preschool teachers at independent kindergartens about how often they include mathematics education in their daily schedules, which sources they use for mathematics education, which methods they use and how they assess themselves in applying the methods. At the end of the studies, it was found after the observations that although most of the teachers stated that they included mathematics activities in their daily schedules, only half of them used these activities. In such situations, observation method should be used to support the scale results in the studies.

It was found in the study that as the level of beliefs of the preschool teachers towards mathematics education increased, the children's mathematics talents score increased as well. In this study teachers expressed belief that early math is necessary for 48 - 60 months old children. Chen, Cray, Adams and Leow (2013), studied about teacher beliefs towards math and children. In that study, a large majority of teachers expressed the belief that early math education is appropriate for young children.

\section{Conclusion}

After the analysis of math skills of 48 - 60 months children, faith and competencies of preschool teachers for mathematics education, and what extent predicted by demographic features of teachers and children; it was determined that respectively the level of teachers' beliefs for the appropriate age for mathematics education of the pre-school period was significantly predicted by age ranges of children, mothers' education level, previously attend pre-school education institution status, gender, father's education level, teachers' level of education, teachers working period in the institution and mothers' working status for the math skills of children. 48 - 60month-old children's mathematics skills improve as their teachers' self-efficacy levels increase. Additionally, the belief levels of the teachers towards mathematics education are directly related to the mathematics skills of the children. The teachers' beliefs towards mathematics education and their perception of the self-efficacy towards mathematics education directly affect the teachers' in-class practices. In the light of the research results it can be said that teachers' beliefs and perceptions of the self-efficacy toward mathematics education are determinative for the math skills of the 48 - 60 months old children.

\section{References}

Aksu, H. H. (2008). Öğretmen adaylarının matematik öğretimine ilişkin öz-yeterlilik inançları. Abant İzzet Baysal Üniversitesi Ĕ̈itim Fakültesi Dergisi, 8, 161-170.

Aslan, Bilaloğlu ve Aktaş Arnas (2006). Okul Öncesi Öğretmenlerinin Günlük Programda Yer Verdikleri Matematik Etkinliklerininve $\mathrm{Bu}$ Etkinlikleri Uygulama Biçimlerinin İncelenmesi. Avrupa Birliği Uyum Sürecinde Okul Öncesi Eğitimin Bugünüve Geleceği Sempozyumu, Girne, Kıbrıs. Cilt I, Sayfa: 243-257. İstanbul: Ya-Pa Yayınları. 
Büyüköztürk, Ş. (2008). Sosyal Bilimler İçin Veri Analizi El Kitabı. İstatistik, Araştırma Deseni SPSS Uygulamaları ve Yorum (6. bask1). Ankara: Pegem A yayınc1lık.

Büyüköztürk, Ş., Çakmak, E. K., Akgün, Ö. E, Karadeniz, Ş., \& Demirel, F. (2010). Bilimsel Araştırma Yöntemleri, PegemA Akademi, Ankara.

Charlesworth, R., \& Lind, K. K. (2013). Math \& Science for Young Children (7th ed.). Belmont: Wadswort Cengage Learning.

Chen, J., McCray, J., Adams, M., \& Leow, C. (2013). A Survey Study of Early Childhood Teachers’ Beliefs and Confidence about Teaching Early Math. Early Childhood Education Journal, 1-11. (In Press)

Creswell, J. W. (2009). Research Design: Qualitative, Quantitative, and Mixed Methods Approaches. Sage.

Erdoğan, S., \& Baran, G. (2006). Erken Matematik Yetenegi Testi-3 (Tema-3)’ün 60-72 Aylar Arasında Olan Çocuklar İçin Uyarlama Çalışması. Çagdaş Ĕ̈itim Dergisi, 31, 32-38.

Ginsburg, H., \& Baroody, A. (2003). Test of Early Mathematics Ability (3rd ed.). Austin, TX: Pro-Ed.

Kandır, A., İnal, G., \& Özbey, S. (2010). Okul Öncesi Eğitimde Program (1) Kuramsal Temeller. İstanbul: Morpa Yayıncilik.

Karasar, N. (2008). Bilimsel Araştırma Yöntemleri. İstanbul: Nobel Yayın Dağıtım.

Platas, L. (2008). Measuring Teachers' Knowledge of Early Mathematical Development and Their Beliefs about Mathematics Teaching and Learning in the Preschool Classroom. PHD Dissertation, Berkeley, CA: University of California.

Şeker, P. T. (2013). Okul Öncesi Öğretmenlerinin Okul Öncesi Dönemde Matematik Eğitimine Yönelik Inanç ve Özyeterliklerinin 48-60 Aylık Çocukların Matematik Yeteneklerine Etkisinin Incelenmesi. Ankara: Yayınlanmamış Doktora Tezi, Gazi Üniversitesi, Eğitim Bilileri Enstitüsü. 